\title{
Temporal trends in non-small cell lung cancer survival in Sweden
}

\author{
DR Brooks ${ }^{*, 1}$, Å Klint ${ }^{2}$, PW Dickman ${ }^{2}$, E Ståhle $^{3}$ and M Lambe ${ }^{2}$ \\ 'Department of Epidemiology, Boston University School of Public Health, 715 Albany Street, Boston, MA 021 I8, USA; ${ }^{2}$ Department of Medical \\ Epidemiology and Biostatistics, Karolinska Institutet, PO Box 28I, SE-I7I 77, Stockholm, Sweden; ${ }^{3}$ Department of Thoracic Surgery, University Hospital, \\ SE-75185, Uppsala, Sweden
}

\begin{abstract}
We modeled temporal trends in the I- and 5-year survival of 32499 patients with adenocarcinoma and squamous cell carcinoma of the lung in the Swedish Cancer Register between $196 \mathrm{I}$ and 2000. The I-year relative survival for adenocarcinoma improved from $37 \%$ for patients diagnosed 1961-1965 to 45\% for those diagnosed 1996-2000 and from 39 to $45 \%$ for squamous cell carcinoma. The adjusted excess mortality ratios for the period 1996-2000 compared with 1961-1965 were 0.80 for adenocarcinoma and 0.8 I for squamous cell carcinoma. Thus, a previous report in a Dutch study of a relatively worsening prognosis for adenocarcinoma over time could not be confirmed.

British Journal of Cancer (2007) 96, 519-522. doi: I 0.1038/sj.bjc.660359| www.bjcancer.com
\end{abstract}

Published online 23 January 2007

(c) 2007 Cancer Research UK

Keywords: lung cancer; adenocarcinoma; squamous cell carcinoma; survival, Sweden

Over the past three decades in many Western countries, there has been a relative increase in the incidence of adenocarcinoma of the lung compared with other histological types (Janssen-Heijnen and Coebergh, 2001; 2003). The same phenomenon has been observed in Sweden, particularly among men (Myrdal et al, 2001). This shift cannot be attributed simply to changes in classification or diagnostic methods (Charloux et al, 1997). It is more likely to reflect the increased use of lower tar and nicotine cigarettes, which are suspected of preferably favouring the development of adenocarcinoma (Wynder and Muscat, 1995; Stellman et al, 1997; Thun et al, 1997).

Data from a regional population-based cancer register in the Netherlands during the period 1975-1994 indicated not only doubling of the relative incidence of adenocarcinoma but also a decline in its relative survival, even as relative survival ratios (RSRs) remained unchanged for other forms of non-small cell lung cancer. It was hypothesised that the decreased survival was also related to increased use of lower-yield cigarettes, and suggested that among adenocarcinomas, those caused by smoking may be more aggressive than those unrelated to smoking (Janssen-Heijnen et al, 2001).

We used nationwide, population-based data for Sweden over a 40 -year period to investigate survival trends for adenocarcinoma compared with squamous cell carcinoma, the other main type of non-small cell lung cancer.

\section{METHODS}

Data for this analysis were derived from the national Swedish Cancer Register (SCR), which was established in 1958. Swedish law

*Correspondence: Dr DR Brooks; E-mail: danbrook@bu.edu

Received 6 October 2006; revised 13 December 2006; accepted I8 December 2006; published online 23 January 2007 mandates the report of all newly diagnosed malignant tumours, as well as benign tumours from selected sites. The completeness of reporting to the SCR has been very high throughout its existence; in 1975, it was estimated that almost $100 \%$ of all malignant tumours were reported (National Board of Health and Welfare, 1980). The SCR uses the ICD-7 to classify primary site and the PAD code, assigned by the diagnosing pathologist, to denote the histological subtype. Approximately $97 \%$ of the cases are morphologically verified with little change over time (National Board of Health and Welfare, 1998).

Criteria for inclusion in this analysis included age 20-80, diagnosis of a malignant lung tumour (ICD-7: 162.1) between 1961 and 2000 and no prior diagnosis of cancer. Because large cell carcinoma and small cell lung cancer were combined as one category until 1985, we limited the analyses to individuals with the two main types of non-small cell lung cancer: adenocarcinoma (PAD: 96) and squamous cell carcinoma (PAD: 146). From the 39714 cases originally eligible, we excluded 7215 individuals who were diagnosed at autopsy or survived less than 1 month after diagnosis. The final dataset consisted of 32499 patients.

Follow-up for mortality is conducted routinely by the SCR through linkage with the Cause of Death Register. We included follow-up for death through the end of 2002 and calculated 1- and 5-year RSRs by sex and histologic type for individuals diagnosed during successive 5-year calendar periods $(1961-1965,1966-1970, \ldots, 1996-2000)$. The RSR represents the ratio of observed survival among individuals with lung cancer to expected survival based on the sex, age (5-year categories) and period-specific mortality of the general population (Ederer et al, 1961). Data for expected survival were derived from population life tables.

To study changes in survival over calendar period of diagnosis for adenocarcinoma and squamous cell carcinoma while adjusting for age and sex, we modelled the excess mortality (observed minus expected) using Poisson regression. The excess mortality ratio 
represents the relative excess mortality within each 5-year calendar period compared with the reference period of 1961 - 1965 (Dickman et al, 2004). We calculated 95\% confidence intervals for both RSRs and excess mortality ratios. Analyses were performed using Stata (Dickman et al, 2007). The study was approved by the Regional Ethics Board of Akademiska Sjukhuset, Uppsala.

\section{RESULTS}

Table 1 provides information on the number of cases of lung adenocarcinoma and squamous cell carcinoma by sex and decade. The proportion of all cases occurring among women doubled from $17 \%$ during $1961-1970$ to $36 \%$ during 1991-2000. Adenocarcinoma steadily increased from $17 \%$ of all cases among men during 1961-1970 to $41 \%$ in 1991-2000. Among women, adenocarcinoma accounted for 60\% of cases during 1961-1990 and increased to $65 \%$ during the most recent period under study (1991-2000).

The 1-year RSR for adenocarcinoma improved from $37 \%$ for diagnoses in 1961-65 to $45 \%$ for $1996-2000$, and from $38 \%$ to $45 \%$ for squamous cell carcinoma (Table 2). The corresponding figures for the 5-year RSR were 14\% (1961-1965) to 17\% (19962000) for both adenocarcinoma and squamous cell carcinoma. Although absolute estimates of relative survival decreased in a separate analysis that included patients dying within 1 month of diagnosis, the survival patterns remained essentially unchanged (data not shown). Even over the specific period (1975-1994) covered by the previous report (Janssen-Heijnen et al, 1998), both 1- and 5-year RSRs remained essentially unchanged in our data for both histologic groups.

The excess mortality ratios, adjusted for gender and age, for the period 1996-2000 compared with 1961-1965 were 0.80 for adenocarcinoma and 0.81 for squamous cell carcinoma (Table 2). For both histologic groups, a substantial fraction of the improvement occurred during the most recent calendar period.

\section{DISCUSSION}

Over the past 40 years, there has been modest improvement in 1-year and little change in 5-year relative survival for lung adenocarcinoma and squamous cell carcinoma in Sweden, most of the improvement being in the last decade, perhaps reflecting more intensive early detection, the introduction of new cytotoxic regimens and implementation of guidelines promoting chemotherapy in advanced disease (American Society of Clinical Oncology, 1997).

Our finding that trends in survival over time were similar for both cell types did not confirm the earlier observation (JanssenHeijnen et al, 1998) of a worsening trend with adenocarcinoma. Reasons for the different results in our studies are not obvious as both were based on population-based registers with similar eligibility criteria and analytical methods. Historically, both smoking prevalence and lung cancer mortality have been substantially higher in the Netherlands than Sweden (Statistics Sweden, 1997; Liaw et al, 2005). Consequently, the proportion of adenocarcinomas attributable to smoking was probably greater in the Netherlands, and this may have contributed to the survival differences. In addition, we cannot rule out differences in diagnostic, treatment or pathological classification practices between the two countries.

The increased incidence of adenocarcinoma observed in Sweden has also occurred on a global scale (Charloux et al, 1997; Jansssen-Heijnen and Coebergh, 2001). Originally, adenocarcinoma was considered to occur primarily among non-smokers (Doll et al, 1957; Kreyberg, 1961), but later studies demonstrated that it is also strongly associated with smoking (Thun et al, 1997; Simonato et al, 2001; Yang et al, 2002). The increased incidence of adenocarcinoma among smokers may be explained by the widespread introduction of filter and lower-tar and nicotine cigarettes (Wynder and Muscat, 1995; Stellman et al, 1997; Thun et al, 1997).

In $1946,50 \%$ of men and $9 \%$ of women in Sweden were daily smokers (www.tobaksfakta.org/default.aspx?id = 3622). Filter cigarettes first became available in Sweden during the late 1950s, whereas reduced tar and nicotine cigarettes were introduced in the early 1970s and now dominate the market. The substantial increase in adenocarcinoma as a proportion of all cases among men over the past 40 years is consistent with early use of non-filter cigarettes followed by a transition to filter and low-tar cigarettes. Because of their later uptake of smoking, women were always more likely to smoke filter and lowtar cigarettes. Adenocarcinoma has always occurred more frequently than squamous cell carcinoma among women. However, cases in the earlier period were more likely to be nonsmoking-related, whereas more recent cases are more likely to be caused by smoking.

Strengths of our study included the nationwide scope, the large number of cases over a 4-decade period and the high case ascertainment. Throughout the study period, less than $3 \%$ of all

Table I Number of lung cancer cases (adenocarcinoma or squamous cell carcinoma only), by calendar period and gender, Swedish Cancer Register $|96|-2000$

\begin{tabular}{|c|c|c|c|c|c|c|c|c|}
\hline & \multicolumn{2}{|c|}{$1961-1970$} & \multicolumn{2}{|c|}{$197 \mid-1980$} & \multicolumn{2}{|c|}{1981 - 1990} & \multicolumn{2}{|c|}{$|99|-2000$} \\
\hline & $M$ & $\mathbf{F}$ & $\mathbf{M}$ & $\mathbf{F}$ & $M$ & $\mathbf{F}$ & $\mathbf{M}$ & $\mathbf{F}$ \\
\hline Overall & $4084(83)$ & $864(17)$ & $6295(81)$ & $|45|(19)$ & $6987(74)$ & $2428(26)$ & $6605(64)$ & $3785(36)$ \\
\hline \multicolumn{9}{|l|}{ Age at diagnosis } \\
\hline $20-40$ & $47(1)$ & $31(4)$ & $53(<1)$ & $30(2)$ & $77(1)$ & $64(3)$ & $40(<1)$ & $55(1)$ \\
\hline $41-50$ & $263(6)$ & $95(||)$ & $323(5)$ & $140(10)$ & $380(5)$ & $257(||)$ & $360(5)$ & $396(10)$ \\
\hline $51-60$ & $1047(26)$ & $214(25)$ & $1368(22)$ & $334(23)$ & $1275(18)$ & $523(22)$ & $1146(17)$ & $915(24)$ \\
\hline $61-70$ & $1843(45)$ & $288(33)$ & $2641(42)$ & $553(38)$ & $2885(4 I)$ & $921(38)$ & $2559(39)$ & $1264(33)$ \\
\hline $71-80$ & $884(22)$ & $236(27)$ & $1910(30)$ & $394(27)$ & $2370(34)$ & $663(27)$ & $2500(38)$ & II55 (31) \\
\hline \multicolumn{9}{|l|}{ Histologic group } \\
\hline Adenocarcinoma & $688(17)$ & $516(60)$ & $1290(20)$ & $87 \mid(60)$ & $2153(31)$ & | $447(60)$ & $2693(4 I)$ & $2473(65)$ \\
\hline Squamous cell carcinoma & $3396(83)$ & $348(40)$ & $5005(80)$ & $580(40)$ & $4834(69)$ & $981(40)$ & $3912(59)$ & $1312(35)$ \\
\hline
\end{tabular}

Percentage within each decade in parentheses. 
Table 2 One- and 5-year RSRs and excess mortality ratios with 95\% Cl over calendar period by gender and histologic group, Swedish Cancer Register, $196 \mid-2000$

\begin{tabular}{|c|c|c|c|c|c|c|c|c|}
\hline & $\begin{array}{l}1961-1965 \\
\%(95 \% \mathrm{CI})\end{array}$ & $\begin{array}{l}1966-1970 \\
\%(95 \% \mathrm{CI})\end{array}$ & $\begin{array}{l}|97|-\mid 975 \\
\%(95 \% \mathrm{Cl})\end{array}$ & $\begin{array}{l}1976-1980 \\
\%(95 \% \mathrm{CI})\end{array}$ & $\begin{array}{l}\text { I } 98 \mathrm{I}-1985 \\
\%(95 \% \mathrm{CI})\end{array}$ & $\begin{array}{l}1986-1990 \\
\%(95 \% \mathrm{Cl})\end{array}$ & $\begin{array}{l}\text { I } 99|-| 995 \\
\%(95 \% \mathrm{CI})\end{array}$ & $\begin{array}{l}1996-2000 \\
\%(95 \% \mathrm{Cl})\end{array}$ \\
\hline \multicolumn{9}{|l|}{ I-year RSR } \\
\hline \multicolumn{9}{|l|}{ Overall } \\
\hline Adenocarcinoma & $37.0(32.8-41.3)$ & $32.6(29.1-36.2)$ & $36.9(33.8-40.0)$ & $40.0(37.2-42.8)$ & $38.0(35.6-40.4)$ & $37.7(35.5-39.9)$ & $39.6(37.6-41.6)$ & $44.7(42.8-46.6)$ \\
\hline $\begin{array}{l}\text { Squamous cell } \\
\text { carcinoma }\end{array}$ & $38.5(36.1-40.9)$ & $40.3(38.2-42.5)$ & $40.7(38.8-42.7)$ & $42.8(40.9-44.6)$ & $44.2(42.4-46.0)$ & $41.4(39.5-43.3)$ & $41.6(39.7-43.4)$ & $45.3(43.2-47.3)$ \\
\hline \multicolumn{9}{|l|}{ Male } \\
\hline Adenocarcinoma & $32.2(26.8-37.8)$ & $30.0(25.5-34.6)$ & $36.5(32.5-40.5)$ & $36.5(32.9-40.1)$ & $34.1(31.1-37.1)$ & $36.6(33.8-39.4)$ & $37.3(34.6-40.0)$ & $41.7(39.0-44.3)$ \\
\hline $\begin{array}{l}\text { Squamous cell } \\
\text { carcinoma }\end{array}$ & $39.0(36.5-41.5)$ & $40.8(38.5-43.1)$ & $41.0(38.9-43.0)$ & $43.3(41.3-45.2)$ & $45.1(43.2-47.1)$ & $41.4(39.3-43.5)$ & $41.6(39.4-43.7)$ & $44.4(42.0-46.9)$ \\
\hline \multicolumn{9}{|l|}{ Female } \\
\hline Adenocarcinoma & 43.1 (36.5-49.6) & $36.1(30.6-41.7)$ & $37.6(32.5-42.6)$ & $44.9(40.5-49.3)$ & $43.9(40.0-47.8)$ & $39.3(35.9-42.7)$ & $42.1(39.2-45.0)$ & $47.8(45.1-50.5)$ \\
\hline $\begin{array}{l}\text { Squamous cell } \\
\text { carcinoma }\end{array}$ & $33.8(26.4-41.4)$ & $35.8(29.0-42.7)$ & $38.0(31.7-44.3)$ & $38.7(33.5-43.9)$ & $39.3(35.0-43.6)$ & $41.3(36.8-45.7)$ & $41.6(37.7-45.5)$ & $47.3(43.4-51.1)$ \\
\hline \multicolumn{9}{|l|}{ 5-year RSR } \\
\hline \multicolumn{9}{|l|}{ Overall } \\
\hline Adenocarcinoma & $13.8(10.9-17.2)$ & $10.9(8.6-13.6)$ & $12.9(10.8-15.3)$ & $13.8(11.9-16.0)$ & $12.5(10.9-14.3)$ & $12.9(11.3-14.5)$ & $14.5(13.0-16.0)$ & $16.7(\mid 5.1-18.4)$ \\
\hline $\begin{array}{l}\text { Squamous cell } \\
\text { carcinoma }\end{array}$ & $14.2(12.5-16.1)$ & $13.6(12.0-15.2)$ & $14.5(\mid 3.0-16.0)$ & $13.9(12.5-15.2)$ & $13.9(12.6-15.3)$ & $14.1(12.7-15.5$ & $14.9(13.5-16.3)$ & $17.1(15.3-18.9)$ \\
\hline \multicolumn{9}{|l|}{ Male } \\
\hline Adenocarcinoma & $12.9(9.1-17.3)$ & $9.3(6.6-12.6)$ & $13.1(10.3-16.2)$ & | I.4 (9.0- |4.1) & $9.9(8.0-12.1)$ & $12.5(10.6-14.7)$ & $11.3(9.5-13.2)$ & $13.4(1 \mid .3-15.7)$ \\
\hline $\begin{array}{l}\text { Squamous cell } \\
\text { carcinoma }\end{array}$ & $14.3(12.4-16.2)$ & $13.4(11.8-15.1)$ & $14.8(13.3-16.4)$ & $14.0(12.6-15.5)$ & $14.1(12.7-15.6)$ & $13.9(12.4-15.5)$ & $13.9(12.4-15.5)$ & $16.9(14.8-19.1)$ \\
\hline \multicolumn{9}{|l|}{ Female } \\
\hline Adenocarcinoma & |5.| (10.6-20.4) & | $3.2(9.4-\mid 7.6)$ & $12.8(9.5-16.6)$ & $17.3(14.0-20.9)$ & $16.3(13.5-19.4)$ & $13.4(\mid 1.0-15.9)$ & $17.9(15.7-20.3)$ & $20.2(17.7-22.7)$ \\
\hline $\begin{array}{l}\text { Squamous cell } \\
\text { carcinoma }\end{array}$ & $13.7(8.6-20.1)$ & $15.2(\mid 0.2-21.0)$ & $11.0(7.3-15.6)$ & $12.7(9.3-16.6)$ & $12.9(10.0-16.2)$ & $14.8(11.6-18.3)$ & $18.1(15.1-21.4)$ & $17.6(\mid 4.4-21.2)$ \\
\hline \multicolumn{9}{|l|}{ Excess mortality ratio } \\
\hline \multicolumn{9}{|l|}{ Overall } \\
\hline Adenocarcinoma & I (ref) & $1.13(1.00-1.28)$ & $0.98(0.87-1.10)$ & $0.91(0.82-1.02)$ & $0.94(0.85-1.05)$ & $0.94(0.85-1.05)$ & $0.90(0.81-1.00)$ & $0.80(0.72-0.88)$ \\
\hline $\begin{array}{l}\text { Squamous cell } \\
\text { carcinoma }\end{array}$ & I (ref) & $096(0.89-1.03)$ & $0.93(0.87-1.00)$ & $0.90(0.84-0.96)$ & $0.87(0.82-0.93)$ & $0.91(0.85-0.97)$ & $0.89(0.83-0.95)$ & $0.81(0.76-0.87)$ \\
\hline \multicolumn{9}{|l|}{ Male } \\
\hline Adenocarcinoma & I (ref) & $1.13(0.96-1.33)$ & $0.92(0.79-1.08)$ & $0.93(0.80-1.08)$ & $0.97(0.84-1.12)$ & $0.88(0.77-1.02)$ & $0.90(0.78-1.03)$ & $0.79(0.69-0.91)$ \\
\hline $\begin{array}{l}\text { Squamous cell } \\
\text { carcinoma }\end{array}$ & I (ref) & $0.96(0.89-1.04)$ & $0.92(0.86-0.99)$ & $0.90(0.83-0.96)$ & $0.86(0.80-0.92)$ & $0.91(0.84-0.98)$ & $0.90(0.84-0.97)$ & $0.81(0.75-0.88)$ \\
\hline \multicolumn{9}{|l|}{ Female } \\
\hline Adenocarcinoma & I (ref) & $1.12(0.93-1.36)$ & $1.06(0.88-1.27)$ & $0.89(0.74-1.06)$ & $0.90(0.76-1.07)$ & $1.02(0.87-1.20)$ & $0.91(0.78-1.07)$ & $0.81(0.69-0.95)$ \\
\hline $\begin{array}{l}\text { Squamous cell } \\
\text { carcinoma }\end{array}$ & I (ref) & $0.92(0.73-1.16)$ & $0.98(0.79-1.23)$ & $0.90(0.73-|| 1)$. & $0.87(0.7|-| .06)$ & $0.82(0.67-1.00)$ & $0.75(0.62-0.9 \mid)$ & $0.7 \mid(0.58-0.86)$ \\
\hline
\end{tabular}

Abbreviations: $\mathrm{Cl}=$ confidence interval; $\mathrm{RSR}=$ relative survival ratio. Estimates are conditional on survival at least I month and are adjusted for age.

cases lacked histological classification. However, we lacked information on stage at diagnosis and were unable to evaluate the trend in the stage distribution by histologic type. JanssenHeijnen et al (1998) found that the proportion of cases diagnosed at a localised stage decreased over the study period for adenocarcinoma but increased for squamous cell carcinoma. We also had no information on smoking, which would have permitted a direct comparison of the survival of persons diagnosed with adenocarcinoma according to their smoking history. One registrybased study in Japan with such information found smoking was associated with poorer survival for adenocarcinoma but not for other histological types (Kato et al, 1990).

In conclusion, we did not find a worsening trend for survival for adenocarcinoma of the lung in Sweden over a 40-year period. Nevertheless, a variety of studies suggests that adenocarci- noma due to smoking differs from other adenocarcinomas (Ahrendt et al, 2001; Ishikawa et al, 2002; Miura et al, 2002; Toyooka et al, 2006). It is too soon to decide whether or not these differences have implications for patient survival. Additional studies with information on tobacco use would help determine whether adenocarcinoma has become more deadly as it has become more common and more closely associated with cigarette smoking.

\section{ACKNOWLEDGEMENTS}

This work was supported by a grant from the Swedish Cancer Society (03-0287). 


\section{REFERENCES}

Ahrendt SA, Decker PA, Alawi EA, Zhu Y, Sanchez-Cespedes M, Yang SC, Haasler GB, Kajdacsy-Balla A, Demeure MJ, Sidransky D (2001) Cigarette smoking is strongly associated with mutation of the K-ras gene in patients with primary adenocarcinoma of the lung. Cancer 92: 1525 1530

American Society of Clinical Oncology (1997) Clinical practice guidelines for the treatment of unresectable non-small cell lung cancer. J Clin Oncol 15: $2996-3018$

Charloux A, Quoix E, Wolkove N, Small D, Pauli G, Kreisman H (1997) The increasing incidence of lung adenocarcinoma: reality or artefact? A review of the epidemiology of lung adenocarcinoma. Int J Epidemiol 26: $14-23$

Dickman PW, Coviello E, Hills M (2007) Estimating and modelling relative survival. Stata $J$ (in press)

Dickman PW, Sloggett A, Hills M, Hakulinen T (2004) Regression models for relative survival. Statist Med 23: 51-64, doi: 10.1002/sim. 1597

Doll R, Hill AB, Kreyberg L (1957) The significance of cell type in relation to the aetiology of lung cancer. Br J Cancer 2: 43-48

Ederer F, Axtell LM, Cutler SJ (1961) The relative survival rate: a statistical methodology. Natl Cancer Institut Monogr 6: 101-121

Ishikawa Y, Furuta R, Miyoshi T, Satoh Y, Okumara S, Nakagawa K, Tsuchiya E (2002) Loss of heterozygosity and the smoking index increase with decrease in differentiation of lung adenocarcinomas: etiologic implications. Cancer Lett 187: $47-51$

Janssen-Heijnen MLG, Schipper RM, Klinkhamer PJJM, Crommelin MA, Mooi WJ, Coebergh JW (1998) Divergent changes in survival for histological types of non-small-cell lung cancer in southeastern Netherlands since 1975. Br J Cancer 77: 2053-2057

Janssen-Heijnen MLG, Coebergh J-W (2001) Trends in the incidence and prognosis of the histological subtypes of lung cancer in North America, Australia, New Zealand and Europe. Lung Cancer 31: $123-137$

Janssen-Heijnen MLG, Coebergh JW, Klinkhamer PJJM, Schipper RM, Splinter TAW, Mooi WJ (2001) Is there a common etiology for the rising incidence of and decreasing survival with adenocarcinoma of the lung? Epidemiology 12: 256-258

Janssen-Heijnen MLG, Coebergh J-W (2003) The changing epidemiology of lung cancer in Europe. Lung Cancer 41: 245-258, doi:10.1016/S01695002(03)00230-7

Kato I, Tominaga S, Ikari A (1990) Lung cancer prognostic factors from the Aichi Cancer Registry. Jpn J Clin Oncol 20: 238-245

Kreyberg L (1961) Relationship of different histological lung tumor groups to tobacco smoking. Br J Cancer 15: $51-53$

Liaw Y-P, Huang Y-C, Lien G-W (2005) Patterns of lung cancer mortality in 23 countries: application of the Age-Period-Cohort model. BMC Public Health 5: 22 doi: 10.1186/1471-2458-5-22

Miura K, Bowman ED, Simon R, Peng AC, Robles AI, Jones RT, Katagiri T, He P, Mizukami H, Charboneau L, Kikuchi T, Liotta LA, Nakamura Y, Harris CC (2002) Laser capture microdissection and microarray expression analysis of lung adenocarcinoma reveals tobacco smokingand prognosis-related molecular profiles. Cancer Res 62: 3244-3250

Myrdal G, Lambe M, Bergstrom R, Ekbom A, Wagenius G, Ståhle E (2001) Trends in lung cancer incidence in Sweden with special reference to period and birth cohorts. Cancer Cause Control 12: 539-549

National Board of Health and Welfare (1980) Cancer Incidence in Sweden 1975-1976. Stockholm: National Board of Health and Welfare

National Board of Health and Welfare (1998) Cancer Incidence in Sweden 1996. Stockholm: Center for Epidemiology, National Board of Health and Welfare

Simonato L, Agudo A, Ahrens W, Benhamou E, Benhamou S, Boffetta P, Brennan P, Darby SC, Forastiere F, Fortes C, Gaborieau V, Germen M, Gonzales CA, Jöckel K-H, Kreuzer M, Merletti F, Nyberg F, Pershagen G, Pohlabeln H, Rösch F, Whitley E, Wichmann H-E, Zambon P (2001) Lung cancer and cigarette smoking in Europe: an update of risk estimates and an assessment of inter-country heterogeneity. Int J Cancer 91: $876-887$

Statistics Sweden (1997) Tobacco consumption 1970-1994 in the Member States of the European Union and in Norway and Iceland. Stockholm: Statistics Sweden

Stellman SD, Muscat JE, Thompson S, Hoffman D, Wynder EL (1997) Risk of squamous cell carcinoma and adenocarcinoma of the lung in relation to lifetime filter cigarette smoking. Cancer 80: 382-388

Thun MJ, Lally CA, Flannery JT, Calle EE, Flanders WD, Heath CW (1997) Cigarette smoking and changes in the histopathology of lung cancer. J Natl Cancer Inst 89: 1580-1586

Toyooka S, Tokumo M, Shigematsu H, Matsuo K, Asano H, Tomii K, Ichihara S, Suzuki M, Aoe M, Date H, Gazdar AF, Shimizu N (2006) Mutational and epigenetic evidence for independent pathways for lung adenocarcinomas arising in smokers and never smokers. Cancer Res 66: 1371 - 1375, doi: 10.1158/0008-5472.CAN-05-2625

Wynder EL, Muscat JE (1995) The changing epidemiology of smoking and lung cancer histology. Environ Health Perspect 103(Suppl 8): $143-148$

Yang P, Cerhan JR, Vierkant RA, Olson JE, Vachon CM, Limburg PJ, Parker AS, Anderson KE, Sellers TA (2002) Adenocarcinoma of the lung is strongly associated with cigarette smoking: further evidence from a prospective study of women. Am J Epidemiol 156: 1114-1122, doi: 10.1093/aje/kwf153 